\title{
Modification of Salix americana willow bark for removal of heavy metal ions from aqueous solutions
}

\author{
Iwona Rypińska*, Marta Biegańska \\ Poznań University of Economics, Faculty of Commodity Science, Department of Industrial Products Quality and Ecology, \\ Niepodległości 10, 61-875 Poznań, Poland \\ "Corresponding author: e-mail: iwona.rypinska@ue.poznan.pl
}

\begin{abstract}
Salix americana willow bark is a waste arising in the process of wicker decortication that so far has not found any practical application. The bark can adsorb metal ions, because in its composition among others are phenolic groups which may be involved in the removal of metal ions from water solutions. The results of sorption of copper(II) and zinc(II) on modified willow bark of Salix americana were presented. The bark was modified with nitric and sulfuric acids at concentrations ranging from 5 to $15 \%$. The best adsorption results were obtained using $15 \%$ nitric acid for modification. Adsorption of metal ions from aqueous solutions at concentrations raging from 20 to 100 $\mathrm{mg} / \mathrm{dm}^{3}$ was studied. It was found that an increase in the initial concentration of copper(II) and zinc(II) resulted in an increase in their adsorption on the modified cortex.
\end{abstract}

Keywords: waste, adsorption, heavy metals, willow bark, methods of modification.

\section{INTRODUCTION}

Strong development of civilization to a large extent contributed to the accumulation of heavy metals in the environment. As a result, these elements are source of contamination of soil, water, plant and animal organisms. Regardless of the forms of occurrence heavy metals pose very large and constantly growing threat to the functioning of ecosystems. Among the many known sources of environmental pollution with heavy metals are particularly troublesome to industrial waste water, resulting of mining, metallurgical, electroplating, production of batteries or in tanning. More stringent and growing requirements concerning the content of metals in treated wastewater introduced into surface water, make use of at the stage of purification of ever newer and more complex chemical processes, projects including ion exchange and adsorp$\operatorname{tion}^{1-3}$. The choice of the process of removing the heavy metals most commonly determined by the form in which these elements are present in the solution. This is due to the $\mathrm{pH}$ values and their concentration in the solution, as well as the presence of organic and inorganic ligands ${ }^{4}$.

The biggest threat to the environment are bioavailable forms of metals present in the form of compounds soluble in water, because they can be easily adsorbed by living organisms. These include, inter alia, copper, zinc, chromium, lead, cadmium and salts thereof. Excessive exposure to copper and its salts can cause serious toxicological concerns. Moreover, it can cause nausea, vomiting, headache, diarrhea, difficulty breathing, renal failure, and consequently death ${ }^{5,6}$. However, zinc can accumulate in the kidneys and liver, cause anemia, and thus reduce absorption of other elements. Zinc is also considered as a carcinogen. That is why it is so important to find the right method for removing heavy metal ions from industrial effluents before they get into the environment.

Wastewater containing heavy metals causes deterioration of water quality which is also affected by the adverse conditions of hydrochemical and destructive act primarily on the biocenosis and inhibit the self-cleaning process. Therefore, according to the Polish law, factories are required to treat sewage. For this purpose, inter alia, physico-chemical methods, which include membrane processes, precipitation, coagulation, ion exchange and adsorption. The choice of method depends on the type and composition of the effluent and the form and concentration of the components removed, and above all, the required degree of purification.

Membrane processes or precipitation of sparingly soluble metal compounds often require strict technological requirements, which carries high economic costs. Therefore, in recent years can be seen a huge interest in adsorption $^{7-10}$, which allows complete removal of heavy metal ions from solutions even at low concentrations. As sorbents natural raw materials and waste from industry and agriculture can be used, which are available in large quantities and do not require complicated processing $^{11-14}$. In addition, they contain in their composition substances such as proteins, polysaccharides and lignin that are associated with functional groups responsible for the adsorption of metal ions. Sorption capacity of raw biosorbents can be enhanced by modification either by physical (e.g. heat treatment, pressure treatment) or chemical methods. However, chemical modification is more effective than physical.

\section{EXPERIMENTAL}

\section{Material}

The bark of willow Salix americana used for the study came from Nowy Tomyśl. Bark fibers were dried at about $100^{\circ} \mathrm{C}$ in a laboratory oven to constant weight. Then portions were crushed into smaller fibers in a blender. For the analyzes was used fraction of bark after sieving $(<0.212 \mathrm{~mm})$, in order to maximize sample homogenity, which was stored in polyethylene containers in a desiccator. All experiments were made in triplicate and only deionized water was used.

\section{Experimental analysis}

Weighed about 6 grams of bark were placed in conical flasks and added $50 \mathrm{~cm}^{3}$ portions of deionized water. Then the flasks were shaken at room temperature under vacuum for $1.5 \mathrm{~h}$, and after that to modify $50 \mathrm{~cm}^{3}$ of nitric $\operatorname{acid}(\mathrm{V})$ at an appropriate concentration was dispensed 
and again shaken from 5 to 180 minutes. After rapid filtration the cortex was washed with deionized water and dried at room temperature for $48 \mathrm{~h}$. In an analogous manner, the modification of the cortex with sulfuric acid(VI) was performed. Weighed portions of approximately $1 \mathrm{~g}$ of the modified bark were treated with of $\mathrm{CuCl}_{2}$ or $\mathrm{ZnCl}_{2}$ at concentrations 20,40 and $100 \mathrm{mg}$ of $\mathrm{Cu}, \mathrm{Zn} / \mathrm{dm}^{3}$, respectively. Initial $\mathrm{pH}$ of all $\mathrm{Cu}(\mathrm{II})$ and $\mathrm{Zn}(\mathrm{II})$ test solutions was about 1.5 (no buffer was used). Then the conical flasks were shaken for 120 minutes at room temperature. After that contents of the flasks were transferred into a centrifuge tubes and centrifuged to separate phases for $15 \mathrm{~min}$ at 4000 revolutions per minute. Subsequently in aliquots of adsorbent above the solution concentrations of $\mathrm{Cu}$ (II) and $\mathrm{Zn}$ (II) were measured by atomic absorption spectrophotometry (F-AAS) at a wavelength $\lambda=324.800 \mathrm{~nm}$ for copper, and $\lambda=213.856$ for zinc.

The surface structure of the Salix americana willow bark was examined in the infrared spectroscope using Fourier transform iattenuated total reflection (FT-IR ATR) Spectrum 100 (Perkin-Elmer, Waltham, USA).

\section{RESULTS AND DISCUSSION}

First stage of the study was carried out to modify willow bark of Salix americana using acids: nitric and sulphuric acids at different concentrations $(5,10$ and $15 \%$ ) and different times of modification (from 5 to 180 $\mathrm{min}$ ). Adsorption of metal ions (A\%) defined as the ratio of decrease in metal concentration after the adsorption $\left(\mathrm{C}_{\mathrm{o}}-\mathrm{C}_{\mathrm{e}}\right)$ to the initial concentration in aqueous solution $\left(\mathrm{C}_{\mathrm{o}}\right)$, was calculated according to the equation ${ }^{15-17}$ :

$A \%=\frac{C_{o}-C_{e}}{C_{o}} \times 100$

In addition, amount of adsorption of copper(II) and $\operatorname{zinc}(\mathrm{II})\left(\mathrm{q}_{\mathrm{e}}\right)$ was calculated using equation ${ }^{15}$ :

$q_{e}=\frac{C_{o}-C_{e}}{W} \times V$

where: $\mathrm{C}_{\mathrm{o}}$ - initial metal ion concentration $\left[\mathrm{mg} / \mathrm{dm}^{3}\right], \mathrm{C}_{\mathrm{e}}$ - concentration of metal ion after adsorption $\left[\mathrm{mg} / \mathrm{dm}^{3}\right]$, $\mathrm{W}$ - weight of adsorbent $[\mathrm{g}], \mathrm{V}$ - solution volume $\left[\mathrm{dm}^{3}\right]$.

Wicker bark is a complex material and the aim of this work was not determination of its components. According to Surmiński ${ }^{18}$ in bark: lignin (ca. $49 \%$ ), cellulose (16-20\%), pentosan (8.5-17.5\%), suberin (2-40\%), extractives $(20-35 \%)$ like tannins, pigments, hemicelluloses, flavonoids, monosaccharides, glycosides, sterols, lipids, terpenes and ash (ca. 0.5-4.0\%) can be found ${ }^{18}$. Good adsorption properties of raw bark ${ }^{19,20}$ induced research focused on sorbent's modification. The purpose of modification was to improve its adsorption properties with acid treatment. Inorganic acids were used as cheap oxidizing agents. Their role was to increase active surface and porosity of bark that was confirmed both by obtained adsorption results of $\mathrm{Cu}(\mathrm{II})$ and $\mathrm{Zn}(\mathrm{II})$ ions and analysis of FTIR spectra of raw and modified material ${ }^{21}$. Additionally, it was presumed that since sulfuric acid behaves as a dehydrating and oxidizing agent carbonization with partial oxidation took place to the cellulose and hemicelluloses as well as partial fragmentation of the lignin components. Modified bark thus was loaded with functional carboxyl and hydroxyl surface groups ${ }^{22}$.
Moreover, when nitric acid was used as modifying agent probably $-\mathrm{NO}_{2}$ surface groups were formed.

The obtained results show that the highest degree of removal of copper(II) and zinc(II) ions was achieved after 5 min of modification process with $10 \%$ sulfuric acid (Fig. 1) in case of copper(II) ions and 5\% sulfuric acid (Fig. 2) in of zinc(II) ions. The willow bark modified with $15 \%$ sulfuric acid was characterized by the smallest adsorption capacity for both metal ions.

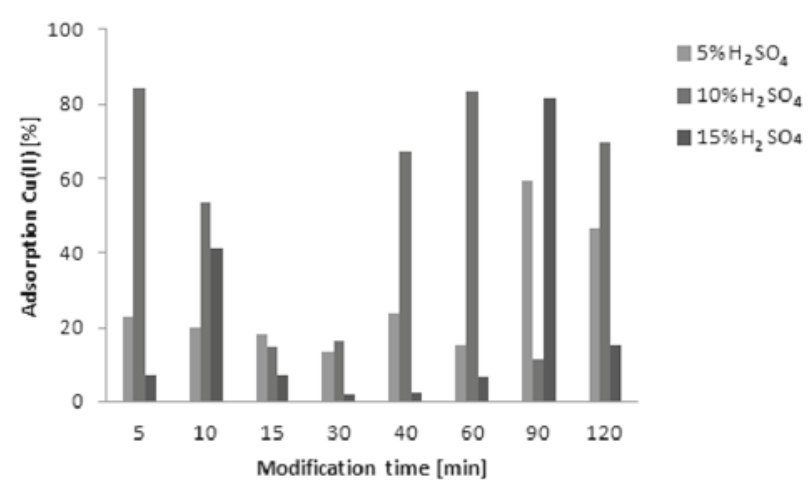

Figure 1. Effect of modification time with 5, 10 and $15 \%$ sulphuric acid on adsorption of copper(II) ions. Shaking time $120 \mathrm{~min}$, initial $\mathrm{Cu}(\mathrm{II})$ concentration $100 \mathrm{mg} / \mathrm{dm}^{3}$

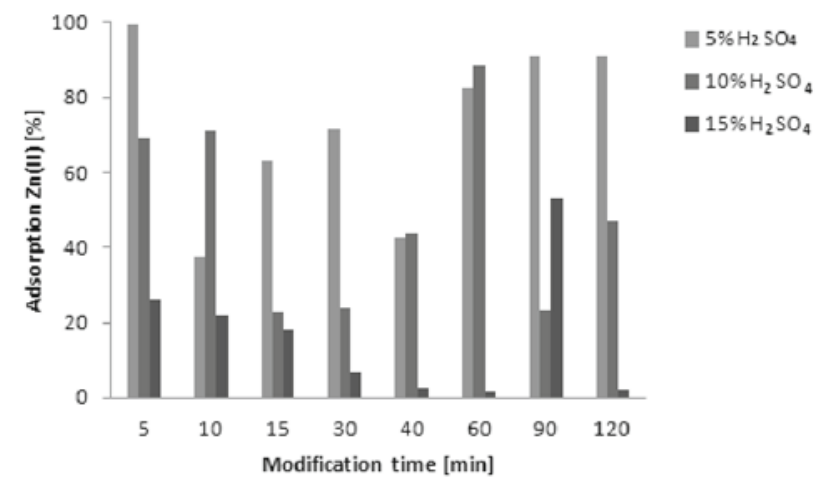

Figure 2. Effect of modification time with 5, 10 and $15 \%$ sulphuric acid on adsorption of zinc(II) ions. Shaking time 120 min, initial $\mathrm{Zn}(\mathrm{II})$ concentration $100 \mathrm{mg} / \mathrm{dm}^{3}$

As a result of modification with nitric acid, it can be seen that the removal degree of zinc(II) and copper(II) from the solutions for all $\mathrm{HNO}_{3}$ concentration and modification times is high (from 80 to 100\%). The highest ion adsorption capacity of $\mathrm{Cu}^{2+}$ and $\mathrm{Zn}^{2+}$ was observed on bark modified with $15 \%$ nitric acid. At the same time the most favorable modification time in case of $\mathrm{Cu}(\mathrm{II})$ adsorption was $120 \mathrm{~min}$ (Fig. 3) and $40 \mathrm{~min}$ in case of Zn(II) (Fig. 4).

With increasing initial metal ion concentrations of the test solution, the amount of ions adsorbed on bark increased. In the case of $\mathrm{Cu}(\mathrm{II})$ adsorption on the bark modified with nitric acid amount of adsorbed metal ions $\left(\mathrm{q}_{\mathrm{e}}\right)$ was almost two times higher than the amount of $\mathrm{Cu}^{2+}$ adsorbed on bark modified with sulfuric acid (Fig. 5). Inverse situation was found in the case of $\mathrm{Zn}$ (II) where amount of adsorption $\left(\mathrm{q}_{\mathrm{e}}\right)$ was greater on bark modified with sulfuric acid (Fig. 6).

However, the mechanism of binding of investigated metal ions on bark's surface was not unequivocally recognized. Metal sorption was accompanied by a decrease 


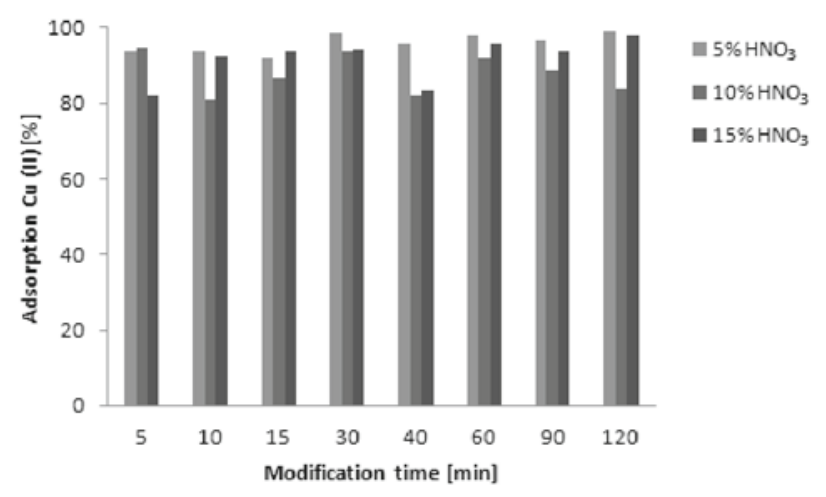

Figure 3. Effect of modification time with 5, 10 and $15 \%$ nitric acid on adsorption of copper(II) ions. Shaking time $120 \mathrm{~min}$, initial $\mathrm{Cu}(\mathrm{II})$ concentration $100 \mathrm{mg} / \mathrm{dm}^{3}$

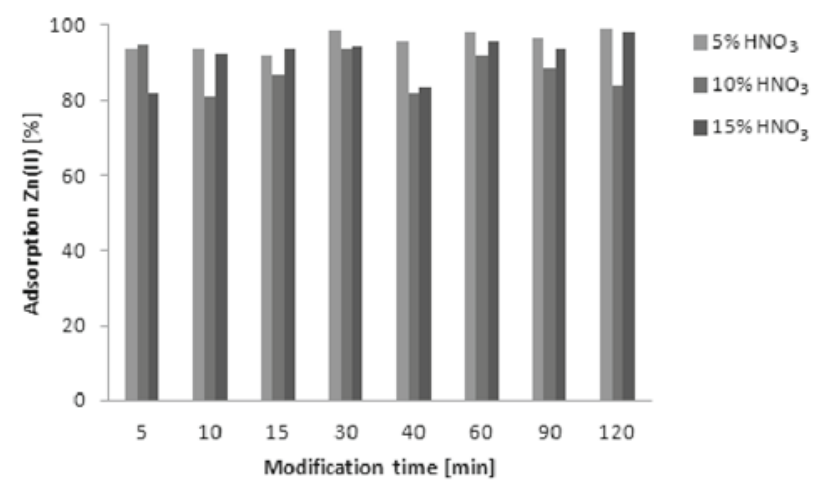

Figure 4. Effect of modification time with 5, 10 and $15 \%$ nitric acid on adsorption of zinc(II) ions. Shaking time 120 min, initial $\mathrm{Zn}(\mathrm{II})$ concentration $100 \mathrm{mg} / \mathrm{dm}^{3}$

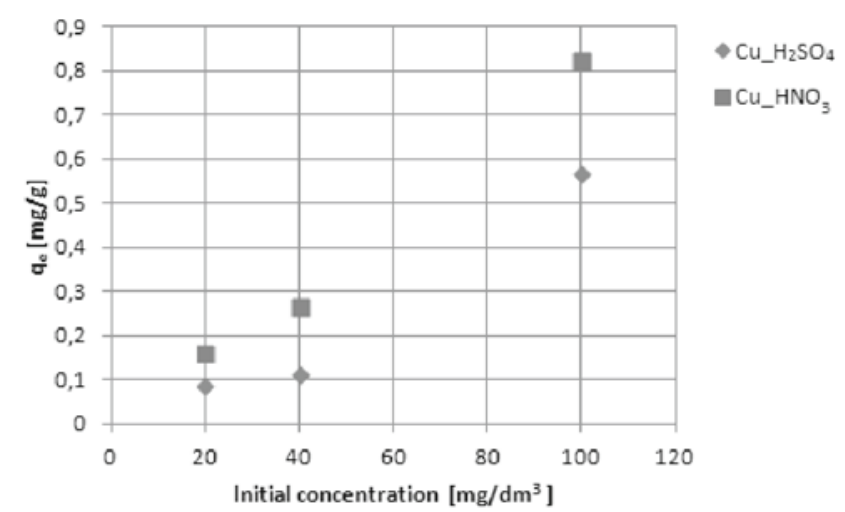

Figure 5. Effect of initial concentration of $\mathrm{Cu}(\mathrm{II})$ on the amount of adsorption $\left(\mathrm{q}_{\mathrm{e}}\right)$. Shaking time $120 \mathrm{~min}$, wicker bark modified with $15 \% \mathrm{HNO}_{3}$ and $\mathrm{H}_{2} \mathrm{SO}_{4}$

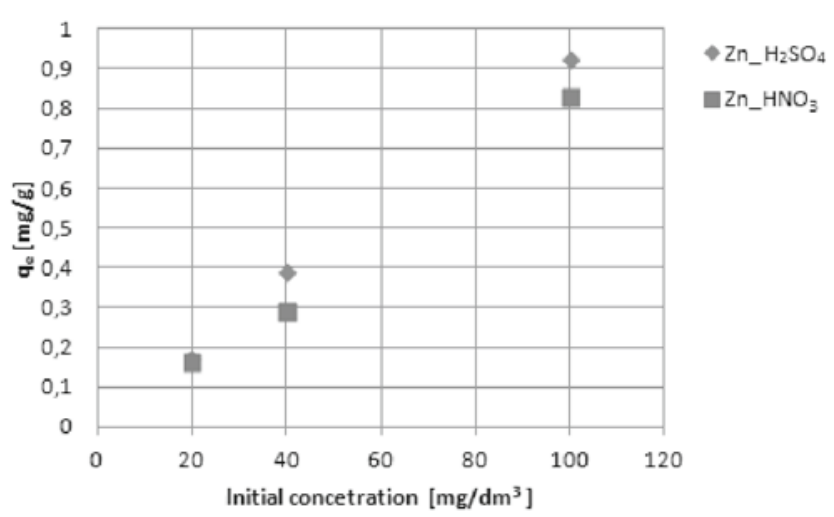

Figure 6. Effect of initial concentration of $\mathrm{Zn}(\mathrm{II})$ on the amount of adsorption $\left(\mathrm{q}_{\mathrm{e}}\right)$. Shaking time $120 \mathrm{~min}$, wicker bark modified with $15 \% \mathrm{HNO}_{3}$ and $\mathrm{H}_{2} \mathrm{SO}_{4}$ in the final $\mathrm{pH}$. This suggest ion exchange mechanism as protons were released in solution. Moreover, on the basis of obtained results and analysis of FTIR spectra of bark before and after adsorption it can be presumed that sorption follows ion exchange and/or complexation mechanism.

\section{CONCLUSIONS}

Tests results of adsorption on modified willow bark Salix americana showed that it can adsorb ions: $\mathrm{Cu}(\mathrm{II})$ and $\mathrm{Zn}(\mathrm{II})$. The bark that was modified with nitric acid occurred to be a better adsorbent of $\mathrm{Cu}$ (II) and $\mathrm{Zn}$ (II) than bark modified with sulfuric acid, and also showed greater amount of adsorption.

The percent removal of copper(II) ions from solution for all the tested modification times and concentrations of $\mathrm{HNO}_{3}$ was similar. However, differences were seen in case of adsorption (A\%) of $\mathrm{Zn}(\mathrm{II})$ at different concentrations of the acid and times of modification. The largest differences were observed in the case of bark modification with $15 \%$ nitric acid, where the $\mathrm{A} \%$ of zinc(II) increased with increasing time of modification.

The most favorable results were achieved after Salix americana modification with $15 \%$ nitric acid. The best results being achieved by modification conducted for $40 \mathrm{~min}\left(\right.$ for $\mathrm{Zn}^{2+}$ ), and $120 \mathrm{~min}$ for $\mathrm{Cu}^{2+}$. However, in the case of modification with sulfuric acid best results were achieved at acid concentration $10 \%$ for copper(II) and 5\% for zinc(II), respectively. In most cases A\% on nitric acid-modified bark was about $100 \%$, while at concentration $40 \mathrm{mg} / \mathrm{dm}^{3}$ percent adsorption of investigated metal ions was approximately $80 \%$.

Furthermore, with increasing metal ions concentration in the solution the amount of ions adsorbed increased. As shown in Figure 5 and Figure 6, the data suggest that with increasing initial $\mathrm{Cu}(\mathrm{II})$ concentration amount of adsorption was higher when bark was modified with $15 \% \mathrm{HNO}_{3}$. Whereas, in case of $\mathrm{Zn}(\mathrm{II})$ with increasing initial $\mathrm{Cu}$ (II) concentration amount of adsorption was higher when bark was modified with $15 \% \mathrm{H}_{2} \mathrm{SO}_{4}$.

On the basis of obtained results it can be presumed that sorption follows ion exchange and/or complexation mechanism.

\section{LITERATURE CITED}

1. Ghodbane, I., Nouri, L., Hamdaoui, O. \& Chiha, M. (2008). Kinetic and equlilbrium study for the sorption of cadmium (II) ions from aqueous phase by eucalyptus bark, J. Hazard. Mater. 152, 148-158. DOI: 10.1016/j.jhazmat.2007.06.079.

2. Chand, R., Narimura, K., Kawakita, H., Ohto, K., Watari T. \& Inoue, K. (2009). Grape waste as a biosorbents for removing $\mathrm{Cr}$ (VI) from aqueous solution, J. Hazard. Mater. 79, 182-190. DOI: 10.1016/j.jhazmat.2008.06.084.

3. Saeiban, M., Klasnja, M. \& Skrbiae, B. (2008). Adsorption of copper ions from water by modified agricultural by- products, Desalination 229,170-180. DOI: 10.1016/j.desal.2007.08.017.

4. Franus, M.(2010). Zastosowanie glaukonitu do usuwania śladowych ilości metali ciężkich, Politechnika Lubelska, Lublin, Polska.

5. Tapiero, H., Townsend, D.M., Tew, K.D. (2003) Trace elements in human physiology and pathology: Copper, Biomed. Pharmacother. 57, 386-398. DOI: 10.1016/S0753-3322(03)00012-X. 
6. Daniel Kenyon, G., Chen, Di, Bing, Yan, Ping \& Dou, Q. (2007). Copper-binding compounds as proteasome inhibitors and apoptosis inducers in human cancer, Front. Bios. 12, 135-144.

7. Dhakal, R.P., Ghimire, K.N. \& Inoue, K. (2005). Adsorptive separation of heavy metals from aquatic environment using orange waste, Hydrometallurgy 79, 182-190. DOI: 10.1016/j. hydromet.2005.06.007.

8. Biegańska, M. \& Cierpiszewski, R. (2010). Wykorzystanie celulozy i kory wierzby Salix americana do adsorpcji miedzi z roztworów wodnych Proceedings of ECOpole 2, 313-317.

9. Dhakal, R.P., Ghimire, K.N., Inoue, K., Yano, M. \& Makino, K. (2005). Acidic polysaccharide gels for selective adsorption of lead (II) ion Sep. Purif. Technol. 42, 219-225. DOI: 10.1016/j.seppur.2004.07.016.

10. Król, S. \& Nawirska, A. (2003). Usuwanie metali ciężkich na wytłokach owocowych w układach dynamicznych Acta Sci. Polon. Technol. Aliment. 2(1), 21-29.

11. Memon, J.R., Memon, S.Q., Bhanger, M.I., Adel El-Turki, A., Hallam, K.R. \& Allen, G.C. (2009). Banana peel: A green and economical sorbent for the selective removal of $\mathrm{Cr}$ (VI) from industrial wastewater, Colloids Surf. B 70, 232-237. DOI: 10.1016/j.colsurfb.2008.12.032.

12. Zvinowanda, C.M., Okonkwoa, J.O., Sekhula, M.M., Agyei, N.M. \& Sadiku, R. (2009). Application of maize tassel for the removal of $\mathrm{Pb}, \mathrm{Se}, \mathrm{Sr}, \mathrm{U}$ and $\mathrm{V}$ from borehole water contaminated with mine wastewater in the presence of alkaline metals, J. Hazard. Mater. 164, 884-891. DOI: 10.1016/j. jhazmat.2008.08.110.

13. Teles de Vasconcelos, L.A. \& Gonzalez Beca, C.G. (1999). Chemical activation of pine bark to improve its adsorption capacity of heavy metal ions. Part 1: by acid treatment, Eur. Water Pollut. Contr. 7, 41-46.

14. Martin -Dupont, F., Gloaguen, V., Granet, R., Gulloton, M., Morvan, H. \& Krausz, P. (2011). Heavy metal adsorption by crude coniferous barks: a modeling study, J. Environ. Sci. And Health, Part A: Toxic/ Hazardous Substances and Environmental Engineering 2, 1063-1073. DOI: 10.1081/ESE-120004523.

15. Dhakal, R.P., Ghimire, K.N., Inoue, K., Yano, M. \& Makino, K. (2005). Acidic polysaccharide gels for selective adsorption of lead (II) ion. Sep. Purif. Technol. 42, 219-225. DOI: 10.1016/j.seppur.2004.07.016.

16. Hamissa, A.M.B., Lodi, A., Seffen, M., Finocchio, E., Botter, R., Converti, A. (2010). Sorption of Cd(II) and $\mathrm{Pb}(\mathrm{II})$ from aqueous solution onto Agave americana fibers, Chem. Eng. J. 159, 67-74. DOI: 10.1016/j.cej.2010.02.036.

17. Śćiban, M., Radetić, B., Kevrešan, Ž. \& Klašnja, M. (2007) Adsorption of heavy metals from electroplating wastewater by wood sawdust, Bioresour. Technol. 98, 402-409. DOI:10.1016/j. biortech.2005.12.014.

18. Surmiński, J., Kora. Budowa anatomiczna, skład chemiczny, możliwości wykorzystania, Wyd. AR, Poznań 1995; Eng. Surmiński J. Bark. Anatomic structure, chemical composition, utilization potential, Poznań University of Life Sciences Publishers, Poznań 1995.

19. Biegańska, M. \& Cierpiszewski, R. (2011). Utilization of agricultural and industrial wastes for metal removal from aqueous solutions, Pol. J. Chem. Technol., vol. 13(1), 20-22, DOI: 10.2478/v10026-011-0004-y.

20. Biegańska, M. \& Cierpiszewski, R. (2010). Utilization of cellulose and wicker bark of Salix americana for copper adsorption from aqueous solutions, Proceedings of ECOpole, 4, (2), 313-317, access 27.01.2014: http://tchie.uni.opole.pl/ ecoproc10b/BieganskaCierpiszewski_PECO10_2.pdf

21. Rypińska, I. \& Biegańska, M. (2013). Adsorption of copper(II) and zinc(II) ions on modified Salix Americana wicker bark, Proceedings of ECOpole, 7(2), 703-710, DOI: $10.2429 /$ proc.2013.7(2)092.

22. El-Shafey, E.I. (2010). Removal of $\mathrm{Zn}(\mathrm{II})$ and $\mathrm{Hg}(\mathrm{II})$ from aqueous solution on a carbonaceous sorbent chemically prepared from rice husk, J. Hazard. Mater., 175, 319-327, DOI: 10.1016/j.jhazmat.2009.10.006. 